\title{
Austerity Politics and Constitutional Crisis in Spain
}

\begin{abstract}
This article explores the political consequences of austerity politics in Spain. It argues that the economic-cum-political crisis in Spain has brought to the surface underlying structural weaknesses of its constitutional edifice accumulated over the past decades. The article sketches the parameters of the current crisis, and provides an account of the dynamic process of crisis and breakdown of Spain's "constitutional regime." It focuses on two inter-related institutional arenas of this regime: the party system, and the territorial model of governance (the so-called Estado de las Autonomías). It analyses developments in both of these arenas, and assesses the emergent opportunities for transition to a new constitutional regime (or regimes), as well as the prospects and policy avenues open for reequilibration. It gives an account of the transition away from two-party politics, and of the rise of new parties such as Podemos and Ciudadanos. It pays special attention to recent events in Catalonia. It argues that the Catalan authorities' defection from loyalty to the constitutional order was triggered in part by the dynamics of austerity, and that it has rendered the country's constitutional edifice - but not the austerity regime - susceptible to collapse.
\end{abstract}

\section{Keywords: Austerity, Constitution, Crisis, Spain, Catalonia}

\section{Introduction}

The financial crisis of the Eurozone, combined with the recipe of austerity imposed in response, have triggered a crisis of democracy in Spain. The crisis is not of the magnitude of the polarizing process that led to the breakdown of the Second Republic, the stalemated coup, and the outbreak of Civil War back in the 1930s, to be sure. But a crisis of democracy it is none the less - more specifically, a crisis of its "constitutional regime." By constitutional regime, we mean "the matrix of institutional relationships and fundamental values that are usually taken as the constitutional baseline in normal political life" (Ackerman 1993, p.59). This article will provide an account of the dynamic process of crisis of Spain's "constitutional regime," focusing on two inter-related institutional arenas of this regime: the party system, and the territorial model of governance (the so-called Estado de las Autonomías). 


\section{A Crisis of the Constitutional Order}

Nearly forty years have passed since Francisco Franco died peacefully in his bed, after nearly forty years of autocratic rule. The in some ways surprisingly smooth transition to democracy that took place after the Generalísimo's death has long been considered a model of reformist, pacted transition by comparativists (Maravall 1982; Colomer 2000; Gunther, Montero and Botella, 2004; Linz and Stepan 1996). The Constitution of 1978 has been hailed as a political achievement of the highest order, depicted as crafted by genuine statesmen from both the regime and the opposition. A broad coalition of political forces with often contradictory programmatic political agendas successfully managed to forge a compromise and consensus in support of a new constitutional democratic order (BonimeBlanc 1987; Oñate 1998).

The crafters of the 1978 Constitution were explicitly motivated by the conviction that the errors of the past were to be avoided at all costs (Aguilar and Oakley, 2002). Their Hobbesian fear of descent into another "fratricidal" civil war was sublimated into a sense of political responsibility, out of which a will to compromise was born, and the Manichean spectre of the two Spain's was exorcised at last. Or so the story went.

In recent years, this hegemonic narrative of the transition has come under considerable attack. Revisionist assessments of the origins and distinguishing characteristics of the current constitutional order have begun to abound, the "regime" itself disparaged, increasingly referred to by the fiercer among its critics as the Second Bourbon Restauration (Doménech 2014; Navarro 2006; Santamaría 2012). 
According to the revisionist critics of the transition paradigm and the so-called Regime of 1978 , the pacted nature of the transition has seriously damaged the quality of democracy in post-transition Spain. The so-called "pact of forgetting" is increasingly challenged, rendered as emblematic not of reconciliation, but of impunity of so many implicated in the crimes of the regime. It is at the same time seen as symptomatic of a certain post-fascist and/or lingering national-Catholic mist continuing to mystify the terms of collective consciousness in contemporary Spain.

The flourishing of revisionist responses to such questions amongst intellectuals in Spain, and - albeit to a lesser degree - among the general public, the increasing willingness to interrogate the foundational myths underpinning the current constitutional order, is certainly partly a sign of "democratic maturity," as the revisionists themselves tend to insist. But it is also at least partly endogenous to the policy-regime of austerity. This policy-regime has entailed a significant reduction in terms of the quality of democracy in Spain, with clear knock-on effects to the legitimacy of the country's "constitutional regime" on the whole. The criterion of "economic responsibility," understood as adherence to the hegemonic policy-regime of austerity, has come to trump and condition alternative criteria such as democratic responsiveness or accountability (Streeck 2011). In more concrete terms, this has meant severe and unpopular cuts in social services, with public spending down 29 billion Euros in 2014 compared to 2009, alongside structural reforms focused on the labor market, which together have undoubtedly contributed to sharp rises in levels of inequality as well as unemployment (Uxó and Álvarez 2016: 3; Busch et. al. 2013: 10). 
After decades of stasis and even decreasing levels of inequality, in post-crisis austerity Spain levels of inequality have increased rapidly, reaching their highest point since the transition to democracy (Primer Informe sobre la Desigualdad en España 2013). Spain currently ranks among the most unequal of countries in the EU, with the top $20 \%$ in terms of income making 6.8 times more than the bottom 20\%, more than double the existing difference in the rate of Sweden, Denmark, Austria, Holland, or Belgium (Maravall 2013; Ayala 2014; Segundo Informe sobre la Desigualdad en España 2015). The costs in terms of public health of the austerity-induced surge in inequality have been well documented (Gili et. al. 2012).

From the onset of the Eurozone crisis up through the middle of 2013, unemployment rose at a worrying pace. The number of unemployed in Spain reached a record $27.1 \%$ in the first quarter of 2013, with unemployment among immigrants at $39 \%$, and youth unemployment at an overwhelming 57\%. Though this disturbing trend has been haulted since, levels of unemployment remain over $20 \%$ (http://www.tradingeconomics.com/spain/unemployment-rate). To make matters worse, "nearly 50 per cent of the 5.5 million unemployed in Spain have been either unemployed for two years or more or have never worked, and there are very high percentages of employed people with part-time or temporary labour contracts" (Uxó et. al. 2016: 165).

From the perspective of constitutional politics, the bleakness of the current conjuncture is perhaps best captured by the collusion in August of 2011 of the socialist Zapatero government with Rajoy's conservative party then in opposition in agreeing to amend article 135 of the Spanish Constitution, the article pertaining to public debt, so as to prohibit budgetary deficits, a move that explicitly imitates a 2009 German reform and 
basically rules out by constitutional fiat recourse to counter-cyclical stimulus packages (Chaqués-Bonafont et. al. 2015: 58-59; Cordero and Montero 2015: 359). They did so without even bothering to consult the demos via referendum about taking such a drastic measure. Their alibi for colluding in this neo-liberal constitutional coup of sorts: credibility in the eyes of financial markets.

Such a credible commitment to the recipe of austerity may well have functioned in terms of placating the idols of international finance, especially after the subsequent victory of Rajoy's conservative party in the general election of December 2011. Even so, the Constitutional pantomime proved damaging to the credibility of the main parties nonetheless, in large part because both main parties (especially the conservative Partido Popular) had spent a good part of the previous decade responding to peripheral-nationalist demands for constitutional reform with a variety of arguments centered around the theme of the need to be cautious before "opening up the Constitutional melon" and fiddling with the great but delicate historic achievement of the exceptionally broad constitutional consensus forged by the founding Fathers of the Constitution and ratified via referendum back in 1978.

Meanwhile, the progressive emaciation of the income and purchasing power of the Spanish popular classes accompanying higher levels of unemployment has led to increasing difficulties for small businesses, and therefore for the Spanish government to secure from tax revenues enough cash in state coffers to continue making payments on the country's sovereign debt. Meanwhile, public debt has continued to creep upwards, and is currently at $99.2 \%$, towering over the $36.1 \%$ of government debt registered before the 2008 bailout of the banks (http://www.tradingeconomics.com/spain/government-debt-to-gdp). 
Simultaneous retrenchments in the realm of economic opportunities, material wellbeing and social rights have in turn set the stage for the exposure of the systemic corruption built into the Spanish political economy. A politics of scandal (Heywood 2007: Jiménez 2004) has re-emerged, in which nearly all of the establishment political parties have been implicated.

From 2013, the governing conservative Partido Popular has faced a serious and ongoing party finance scandal, implicating many of the party's most prominent figures, including several cabinet members, not to mention Prime Minister Mariano Rajoy (and the former one, José María Aznar). So too has the conservative Catalan nationalist Convergència Democràtica been plagued by a string of scandals, including most notably the confession of tax evasion and money laundering via secret Swiss and Andorran bank accounts by the ex-President of the Generalitat, Jordi Pujol. Nor has the socialist opposition manage to escape the muck, though the main corruption scandals affecting it would pertain mostly to the local level, where all the main parties have been implicated in widespread practices of misusing public funds for personal gain and accepting bribes in exchange for concessions of licenses for construction during the housing-market boom (Jiménez 2009).

Against this backdrop of scandalous revelations still working their way through the judicial system and widely reported in the mass media, higher and higher percentages of the Spanish public have come to perceive corruption to be one of the main problems confronting the country. As late as 2012 , less than $10 \%$ of the Spanish public had mentioned corruption among the main problems confronting the country; but by 2013 , the proportion surpassed 30\%, and now hovers around nearly $40 \%$ (http://www.cis.es/cis/opencm/ES/11 barometros/index.jsp). Indeed, an increasing 
proportion of the public seems to have concluded that the series of corruption scandals rocking the political establishment is not just an issue of a few or even a lot of "bad apples"; rather, such scandals reflect the workings of a system corrupted to the core (López 2014; Villoría et. al. 2013; Santamaría 2012).

\section{Transformations in the Party System}

But every crisis brings with it new opportunities. The very same stresses on the social fabric caused by the sharp rises in inequality, high unemployment, cuts in welfare services, and the exposure of systemic corruption has created an ideological climate more propitious for "contentious" brands of politics and even of popular mobilization, if not exactly the awakening of long-dormant, perhaps defunct, militant class consciousness.

Which brings us to the first institutional arena in which the crisis of Spain's "constitutional regime" has emerged - namely, the crisis of the party system (Wilson 2012; Gunther et. al. 2004). How best to capture the significance of this dimension or institutional arena of constitutional crisis? Here Antonio Gramsci's notion of "organic crisis" remains useful. According to the still-unsurpassed theorist of hegemony, such crises take place when large segments of the population (in Gramsci's view, social classes) "become detached from their traditional parties" - more specifically, when they become detached from the "particular organizational form, with the particular men who constitute, represent, and lead them" (1971: 210). In these situations, the representatives of the main established parties are no longer recognized by core constituencies as genuine "expressions" of the group. Furthermore, as Lustick has likewise elaborated, for Gramsci, at the origin of these "organic 
crises," there lie "drastic changes which bring to light 'incurable contradictions' " contradictions which in turn "undermine the self-confidence of state elites and ruling groups and weaken the ability of prevailing conceptions to limit entry of new kinds of questions into the public domain" (1993: 122).

Anyone paying attention to the drama still unfolding on the Spanish political stage can easily recognize similarities with the patterns described above by Gramsci and Lustick, even if the "incurability" of the contradictions remains an open question, and "reequilibration" a distinct possibility. The financial crisis and the response of austerity has meant for Spain the bursting of a bubble much bigger than that of the housing market alone. Indeed, it has entailed a "drastic change," one that has brought to light serious 'contradictions', though whether these will prove "incurable" remains an open question.

The first sign that a "drastic change" was underway came in May of 2011, when the Indignado or 15-M movement erupted onto the Spanish political scene with an impressive display of relatively spontaneous popular force (Calvo 2013). The people who came out in protest over the policies of austerity to occupy public squares in May of 2011, with waves of indignant citizens overflowing out of Madrid's Puerta del Sol and Barcelona's Plaza de Catalunya, drew significant international attention, eliciting comparisons with the Arab Spring, especially events in Tahir square (Muñoz et. al. 2014). The emblematic slogan of the Indignados directly called into question the democratic quality of the country's representative institutions: "iNo nos representan!" Indeed, the phrase "Spanish revolution" even briefly enjoyed a certain present-tense, non-ironic resonance for the first time in over seven decades. 
Even so, the crowds soon thinned and the occupations were eventually dismantled, with the help of some strong-armed police tactics. And in November of 2011, the Spanish demos chose to hold the incumbent socialist administration accountable for its performance by rendering a decisively anti-revolutionary electoral verdict that gave an absolute majority to the conservative Partido Popular (Anduiza et. al. 2014).

Yet the conservatives' electoral victory did not signal an end to widespread disenchantment; to the contrary, the country's representative institutions, especially its two main state-wide political parties, would remain the objects of much contempt by broad swathes of the demos throughout a legislature that began with unprecedented cuts -27 billion euros slashed from the 2012 budget, with health and education hit the hardest - and included other controversial measures such as freezes in the wages of civil servants as well as an important liberalizing labor market reform (Legido-Quigley et. al. 2013; Cordero and Montero 2015; Uxó et. al. 2016).

In 2013, the Partido Popular would be engulfed in scandal with the exposure of a parallel accounting system and illegal slush fund for prominent party officials. This was brought to light by the publication in El País of the handwritten account ledgers by former party treasurer, Luís Bárcenas, a scandal which significantly undermined the credibility of Mariano Rajoy's government. However, the socialist opposition proved incapable of taking advantage of the scandal. The public seemed still unwilling to forgive them for their management of the economy after the bursting of the bubble in 2008 , and certainly still remembered the PSOE's long record as an establishment party, especially its direct implication in the systemic corruption of the pre-crisis period. As a result, the PSOE 
remained even more discredited in the eyes of a Spanish electorate ever more angry at the political status quo.

In the wake of the Bárcenas scandal, clear signs could be detected in public opinion surveys that major transformations in the country's party system were looming on the horizon. The first casualty of such realignment would be the longstanding trend towards a two-party system. This trend had been "progressively accentuated during the first thirty years of democracy, up through the election of 2008, in which the PP and the PSOE together concentrated $84 \%$ of votes and $92 \%$ of seats" (Barreiro 2013). In 2011, for the first time this was not the case - "the two parties did not increase their combined proportion of support," though the concentration of the votes and seats remained very high, at $73 \%$ of votes and $85 \%$ of seats, respectively.

In the European elections of May 2014, a new political force erupted onto the scene - Podemos, with its impressive baptismal performance of five Euro-deputies (Cordero and Montero 2015). Podemos would initially derive its legitimation from the Indignado movement, though its early flirtation with Assembly-style direct democracy soon gave way to a high degree of centralized plebiscitary control around the figure of Pablo Iglesias and a highly-cohesive group of his academic friends. The young political scientists from the Complutense University in Madrid at the helm of the new party demonstrated a significant amount of tactical agility in spreading their counter-hegemonic critique of the "political caste" in the mass media. They openly called for a "constitutive moment," even a "rupture" with the governing "regime" (Delclós 2014; Flescher Fominaya 2014; Stobart 2014). In the weeks and months following the European election, Podemos would surge in opinion polls. 
By the end of the year, the party was even polling first in some surveys of projected votes among the Spanish public.

Hopeful commentators on the left across Europe and in North America were quick to predict an impending victory for the upstart party. The politics of austerity, they insisted, was destined to fundamentally alter the balance of class forces in favour of the materially dominated and the dispossessed in Spain, just as it had in Greece. The regime of austerity was doomed.

There was even talk of an impending PASOK-ization of the PSOE. The sky seemed the limit for the upstart Podemos in the second half of 2014. But there was much wishful thinking in this premature diagnosis. The comparison with Greece was in important ways misleading. For starters, the Spanish economy is much bigger than that of Greece, its state more capable of collecting taxes from the middle and upper classes (though no analyst would deny that upper class tax evasion is widespread in Spain as well). Perhaps more crucially, the contraction of the Spanish economy after the bursting of the bubble, painful though it has been, simply pales in comparison to the veritable freefall experienced in Greece, where the contraction has been worse than any experienced in Europe since the Great Depression.

Syriza's victory in January of 2015 was hailed as a harbinger of good things to come amongst Podemos enthusiasts inside and outside of Spain at the time, to be sure. But before long, the difficulties that the Tsipras government encountered in fulfilling its campaign promise and converting its electoral success into an effective break with austerity within the Eurozone appeared to have a knock-on effect on perceptions of Podemos as well. By the time Tsipras surrendered to the Troika in July, Podemos was looking much less like 
the "center of Spain's new political game-board." The promise of a break with austerity within the Eurozone had come to seem ever more likely a contradiction in terms, a utopian fantasy, a populist fib. Needless to say, this turn of events in Greece would contribute to a decline in support for Podemos, rendering its purposely vague electoral promises less plausible in the eyes of the Spanish public. After peaking at $23.9 \%$ of intended votes in January of 2015 , the proportion projected had fallen to $16.5 \%$ by April, and to $15.3 \%$ by July (http://elpais.com/elpais/2015/08/04/media/1438681849 641670.html).

In sum, the difficulties encountered by the Syriza government served as an ideological stick of sorts, reinforcing the hegemonic perception that There Is No Alternative (TINA) to the policies of neoliberal austerity - at least not one that does not entail a very unpopular exit from the Eurozone. Worse yet, these difficulties were portrayed in mainstream Spanish press as evidence that any attempt to pursue an alternative is only likely to make things worse.

The difficulties of Podemos after its brief honeymoon in the court of Spanish public opinion cannot be pinned on the problems of Syriza alone. Multiple domestic factors were at work as well. Perhaps foremost among them would be certain indicators of economic recovery - significant enough to render credible the claims of the advocates of austerity that the sacrifices have not been for naught, that there is light at the end of the tunnel.

The economy began growing again in the second trimester of 2013, and has continued growing ever since. By June of 2015 an OECD report was projecting "robust growth ... over the next two years," growth which it claimed would be "driven by very supportive financial conditions, the depreciation of the euro, lower oil prices and strengthening trading partner growth" (http://www.oecd.org/eco/outlook/spain-economic- 
forecast-summary.htm). In addition to the stick of the Syriza example, then, positive economic indicators provided an ideological carrot as well, rendering sufficiently plausible the claims of the government about light at the end of the tunnel.

Perceptions are of course crucial here, and for the vast majority of citizens, at least, hardly based on anything approximating reflective equilibrium. As Przeworski has forcefully argued, in general "people are willing to suffer in the short run," so long as "they believe in the long run." But in representative democracies, politicians have to get elected and reelected. This poses a serious problem for any party running on a platform promising sacrifices in the short run, simply because "people do not know how long the transition will be." Indeed, painful economic reforms represent a "plunge into opaque waters," in which people neither "know where the bottom is" nor "how long they will have to hold their breath" (1991, p.168). Confidence, thus, intervenes, shaping popular reactions.

Rebounding confidence in the Spanish economy would be especially strong amongst Spanish businessmen, and was even detectable before the economy had begun to grow again, as reflected in the Industrial Confidence Indicator, which began consistently creeping upward from the beginning of 2013, and had reached pre-crisis levels by the end of 2015 (http://www.tradingeconomics.com/spain/business-confidence). Indicators of consumer confidence have followed suit (http://www.tradingeconomics.com/spain/consumerconfidence). Even so, the proportion of the Spanish public perceiving the economy to be in good shape in the present has remained dismal and stagnant since 2009 , at under $10 \%$. Crucially, however, the proportion of Spaniards who fear that the economy will be worse in a year's time, which reached $40 \%$ in 2013, has since plummeted. By mid-2016, it was a mere $15 \%$, well under pre-crisis levels 
(http://www.cis.es/cis/opencm/ES/11 barometros/index.jsp). With such rebounding confidence in the Spanish economy, the appeal of any promise to break with the economic status quo, and thus the prospects for Podemos, took a turn for the worse.

The mass media played a significant role in both the spectacular rise and subsequent cooling off of public opinion towards Podemos as well. Pablo Iglesias emerged in 2014 as a veritable media celebrity, his ubiquitous presence and strong performance on the talk show circuit consistently impressive. But the initially near-universal benevolent coverage of the new party predictably gave way to more sceptical treatment in 2015 , especially as the December general election approached, with right-wing media waxing hysterical about alleged links to Venezuela and even Iran.

Much of the initial enthusiasm surrounding Podemos was linked to the hope that it could ride the wave of citizen indignation - so powerfully expressed in the $15 \mathrm{M}$ movement straight into the Moncloa. The image they relied on was that of a political tsunami capable of wiping away the country's deeply entrenched clientelistic networks and systemic corruption, the so-called casta.

But the Indignado movement was never anything close to a tsunami. Even in its hay day, the proportion of Spaniards mobilized into the movement was very low - the absolute majority won by the PP in the general election just a few months after the eruption of $15 \mathrm{M}$ in 2011 the clearest reminder of this inconvenient fact, despite how powerful that wave of social mobilization might have appeared in the twitter-sphere or on Facebook newsfeeds. Even worse, much evidence suggests that the Indignado movement never managed to incorporate or mobilize the working class strata most devastated by the current crisis. The same is unfortunately true for Podemos as well (Calvo and Alvarez 2015). 
The sad truth is that the Indignados were always a distinct minority; the depoliticized, apathetic and quiescent majority of Spaniards can more aptly be described, not as Indignados, but rather, as resignados. The prospect of mass mobilization, expansion of participation and consciousness, much less the re-articulation and transformation of dominant social imaginaries and fissures, remains far-fetched.

Nor should the status quo biases entrenched in Spain's electoral laws be forgotten. These laws both (1) over-represent the conservative countryside and (2) punish electoral divisions, especially on the left (Montero 1997). Which is why more cynical commentators close to the PSOE even conjectured complicity on the Spanish right in promoting the mass media's early love affair with Pablo Iglesias, all in the name of the game of electoral divide and conquer.

Such conspiracy theories notwithstanding, the threat posed to the "left" of the political spectrum by the end of the trend towards "bi-partyism" would prove very real. The December 2015 general election witnessed a clear surge in terms of support for parties on the "left" in comparison with the result of the 2011 general election, when the PSOE and IU had managed to capture together just over $35 \%$ of all votes cast. By contrast, in December of 2015, the proportion that voted for either the PSOE or Podemos or IU would rise to over 46\%, almost $2 \%$ better than the PP's 2011 performance. Even so, this $46 \%$ would be divided across three parties, in an electoral system built to punish divisions, especially on the left, and thus translated into 25 fewer seats than those won by the PP in $2011-14$ fewer than what would be needed for a majority in the Congreso de Diputados, even assuming the political will for such a left-leaning coalition could be mustered. 
The PSOE fared the best among the nominally left-leaning options in the December 2015 election. Now led by the young and dapper, but "responsible," Pedro Sánchez generational renewal of the casta having been achieved at the very top of the party already, in no small measure in response to the threat posed by Pablo Iglesias on the populist left their proportion of the vote was down 6\% from 2011, at 22\%, which translated to 90 seats. They thus managed to fend off the fate of PASOK-ization, despite registering their worst result since the transition to democracy.

But Podemos was right at their heels - performing better than the majority of polls had predicted, with nearly $21 \%$ of votes, though this translated into significantly fewer seats, 69. Not surprisingly, this impressive surge did great damage to the electoral fate of the post-communist IU, which after deciding against a coalition with Podemos and presenting itself in a truncated coalition named (with a good dose of unintentional irony) Unidad Popular en Común, hemorrhaged votes and seats, down from $6.9 \%$ to $3.7 \%$ of the vote, and from 11 to 2 seats. Commentators on the left were quick to draw the conclusion that the failure to consummate a "confluencia" ("coming together") had been a tactical error for both formations. Such commentators pointed to the municipal elections in May of 2015, in which coalitions embodying such "confluencia" between Podemos and IU/IC (Ahora en Común and Barcelona en Comú) emerged victorious in the country's two biggest cities, to buttress their case. And to the fact that in the general election, together, the number of votes received by the two formations would have translated into 85 instead of 71 seats, which in turn would have both strengthened the overall representation of nominal leftleaning formations and the "real" left vis-à-vis the "nominal" or center-left 
(http://www.eldiario.es/politica/GRAFICO-Congreso-Podemos-confluencias-

IU $0 \quad 464754323 . h t m l)$.

A problematic conclusion - and one that the leadership of Podemos had resisted, most vocally Iñigo Errejón, who had famously insisted that Podemos should try to distance itself from the language of "left" versus "right." Of course, such distancing was always going to be a difficult sell, given the aesthetics, the rhetorical style and the background of its leaders. And in the run-up to the general election, it soon became apparent that the Spanish public was unpersuaded by the idea that Podemos was somehow beyond left and right. Indeed, the CIS's pre-electoral survey showed that the public perceived the new party to be clearly situated to the left of the Socialist party and even to the left of the postcommunist IU, with 52\% viewing Podemos as located at either a 1 or 2 on a 1 to 10 left-right spectrum (and an average of 2.09), compared with only 43\% so viewing IU (avg. 2.46) (and $6.8 \%$ so viewing the socialists, avg. 4.38) (http://www.cis.es/cis/export/sites/default/Archivos/Marginales/3100 3119/3104/es3104mar.pdf). This widespread perception of Podemos as situated near the "extreme" left revealed the difficulties inherent in the upstart formation's aspiration to form a truly counter-hegemonic bloc, and fixed a definite ceiling to its electoral appeal.

Yet Podemos was heartened by its performance in the December election, and believed momentum to be on its side. It thus succumbed to the illusion of an imminent sorpasso, so struck a confident, even belligerent tone, in the weeks and months that followed. At the same time, it worked on securing a consummated coalition with Izquierda Unida this time around, in preparation for a snap election it hoped could resolve the stalemated result of the December contest, and perhaps even catapult it into power. A 
miscalculation, it turns out, but one that did not go uncontested at the level of the leadership (with echoes amongst the rank-and-file), pitting Iglesias against Errejón.

Nor would partisan divisions be limited to the "left" of the political spectrum. As public opinion began to cool towards Podemos in the first four months of 2015, another "anti-establishment" alternative surged - one not widely perceived to be on the left: namely, Ciudadanos ( $C^{\prime}$ s), a party that has been around since 2006 in Catalonia but only recently began organizing at the state-wide level. It was originally, and to a significant extent still remains, a single-issue party of sorts - its issue being the defence of Spanish unity. In January of $2015, C^{\prime}$ s was polling at $3 \%$, but by April its proportion of intended votes had increased to $14 \%$ (http://www.cis.es/cis/export/sites/default/Archivos/Marginales/3100 3119/3104/es3104mar.pdf).

Ciudadanos would represent a serious electoral threat to the ruling Partido Popular. Its leader, Albert Rivera, is a well-groomed, well-dressed, and well-spoken young man, almost as handsome as socialist Pedro Sánchez, though not as tall. Throughout 2015, Rivera consistently polled as the country's most popular politician, with $50 \%$ of the Spanish public registering their approval of him, well ahead of the 38\% registered for Sánchez, much less the $31 \%$ for the pony-tailed Pablo Iglesias, and the mere $25 \%$ for the old, bearded Prime Minister (http://electomania.es/metroscopia-el-psoe-ganaria-las-elecciones-caepodemos/).

There are more substantive reasons why C's has posed a threat to the PP as well. Crucially, the party has remained virtually unsullied by implication in the country's systemic corruption, largely because of its relative absence from municipal level politics. Moreover, the Spanish public perceives C's as being situated on the center-right of the ideological 
spectrum, with an average of 6.18 on the 1 to 10 scale. This score is much closer to the center than the PP, which is perceived to be near the far-right by Spaniards, at an average of 8.26. Indeed, even those who admit to having voted for the PP in the 2011 general election perceive the ruling party to be situated on average at 7.59 , well to the right of where they place themselves (on average 6.60) (http://www.cis.es/cis/export/sites/default/Archivos/Marginales/3100 3119/3104/cru3104votog2011.html). Yet, in terms of party program and potential populist appeal, because of its impeccable credentials when it comes to defending the Spanish nation, Ciudadanos is nevertheless hard to outflank on the Spanish-nationalist front.

Despite this threat, the Partido Popular still received the most votes in the December election, though with a mere $28 \%$, nearly $16 \%$ lower than in 2011, which translated into 123 seats in the Congreso de Diputados, down from 186, and 52 shy of an absolute majority. For its part, Ciudadanos received a respectable $14 \%$ share of votes, which translated into 40 seats.

All told, the result of the December 2015 election was a virtual stalemate, with a fragmented and polarized Congreso de Diputados that would prove incapable of forming a new government. New elections were called for the end of June. In the meantime, Rajoy remained at the helm of the now interim government. A half a year of interim or nongovernment, in which, as we have seen, indicators of confidence in the Spanish economy continued to rebound, and in which no new painful austerity measures could be passed.

In March, the Budget Minister released the country's deficit figures for the previous year, which stood at $5.16 \%$ of the GNP, well above the $4.2 \%$ the government had promised Brussels, not to mention the $3 \%$ limit fixed in the Eurozone's Stability Pact (which the 
country exceeded for the eighth straight year). This despite the fact that Spain had grown an impressive 3.2\%, twice the rate of the Eurozone as a whole (http://economia.elpais.com/economia/2016/03/31/actualidad/1459418481 044567.html). Just weeks before the snap election, the Troika would publish a report on the country, in which it would issue praise for the government for its handling of the economy, but would also lament "the relaxation of fiscal consolidation," singling out for particular admonishment the Regional Governments and the Social Security system (http://www.elmundo.es/economia/2016/06/17/57641775e5fdeadb418b4589.html).

It was in this economic climate that the second election took place. An election which again failed to deliver a clear majority, and thereby perpetuated the country's political stalemate, albeit with non-identical results. Apathy nudged up, participation went down, more than $3 \%$, to just under $70 \%$. The Partido Popular, still much weakened compared to 2011, nevertheless came out relatively strengthened this time around, up nearly 700,000 votes, raising its share more than 4 points, to $33 \%$, and increasing its number of seats 14 , up to 137 . For its part, Ciudadanos again performed respectably, though it was down over half a percentage point, for which it was punished, losing 8 seats, leaving it with 32, leaving a hypothetical PP-C's parliamentary alliance still 7 seats short from the majority required for securing the investiture of a prime minister and the formation of a new government.

Meanwhile, on the left of the representative spectrum, the much-anticipated sorpasso of the socialists by the electoral coalition Unidos Podemos failed to materialize. The much-touted "confluencia" between Podemos and Izquierda Unida did not bear fruit. After "coming together," the coalition Unidos Podemos lost over a million votes from what 
they had managed to sum separately a half year earlier, though they equalled their number of seats. As for the socialists, they too lost votes (fewer), and lost 5 seats as well, though the mere fact that they had fended off the sorpasso led these results to be received with a palpable sense of relief by party leaders and friendly press.

The Brexit referendum took place just three days before the second election in Spain, and the shockwaves emanating from the verdict of the British people were soon felt in the Iberian peninsula. At the end of July, the European Commission announced it would cancel fines against Spain and Portugal for failing to comply with the Eurozone's budgetary rules. It was reported that last-minute lobbying by none other than German Finance Minister Wolfgang Schauble had convinced Commissioner Junker to reverse course (http://www.politico.eu/article/no-fines-for-portugal-spain-over-budget-failures-europeancommission-deficit/).

Apparently, in the aftermath of the Brexit vote, European authorities have come to conclude that avoiding further damage to the EU's much tarnished image is a top priority indeed, an even more pressing concern than any credibility sacrificed by failing to enforce "fiscal consolidation" within the Eurozone. No doubt, these same authorities have been paying close attention to the political stalemate in Spain, and rationally fear that heavyhanded, punitive measures could backfire and render more salient anti-austerity sentiment across the peninsula, which could in turn potentially undermine "the substantial efforts" and "ambitious structural reforms" already undertaken by national authorities over the past several years.

Which is not to say that European authorities are no longer concerned with "fiscal consolidation." To the contrary, they remain very worried, and with each passing month of 
interim government more nervous. Nor is it a secret that these same authorities firmly desire to see a government capable of passing new legislation and delivering on the country's promises to EU institutions. In the week after the second election, ex-Prime Minister Felipe González intervened to air such concerns in an op-ed in the pages of El País, in which he implored: "We have already lost eight months in this strange interim situation. It is only logical that we put an end to this situation as soon as possible, which would be best for everybody, or at the very least, least costly" (http://elpais.com/elpais/2016/07/06/opinion/1467826976_877593.html). The message for his remaining followers: the socialist party should abstain in the second round of voting for Rajoy's investiture, out of a sense of political responsibility.

Easier said than done. Divisions among the socialists have abounded since the June election - with some fearing that the party's core constituency will punish them in the next election if they allow the PP to govern (http://www.lavanguardia.com/politica/elecciones/20160627/402792223557/psoedescarta-apoyo-abstencion-rajoy.html). Meanwhile, a chastened Podemos leadership has taken to courting the socialists, urging Sánchez to consider heading an alternative government along the lines of the socialist-led left-coalition now in power in Portugal (http://okdiario.com/espana/2016/08/16/podemos-insiste-psoe-gobierno-alternativo-rajoy320370).

In the aftermath of the June election, Sánchez was quick to recognize the PP as victor, and to blame the "intransigent" Pablo Iglesias, whom he accused of having let personal and partisan interests squander the opportunity to form a progressive coalition after the December election, when it had existed, clearly implying such an opportunity no 
longer existed, that the PP had won the prerogative to govern (http://www.20minutos.es/noticia/2782857/0/elecciones-generales-2016-psoe-pedro-

sanchez/). Though he has yet to facilitate this option.

In previous electoral cycles when absolute majorities were absent, Catalan and Basque nationalist forces have lent support and secured a stable government in Madrid, usually in exchange for measures increasing devolution. But the rise of Ciudadanos has stymied this formula.

Which brings us to the subject of Catalonia. Neither the rise of Ciudadanos nor the relative buoyance of the Partido Popular - the fact that ever since 2011, the most reputable opinion polls have consistently found the PP to rank as the most popular party in the country (or at least the least unpopular party), despite stratospheric unemployment, despite the Bárcenas scandal - none of this would be in the least likely were it not for the climate of nationalist polarization around Catalonia.

\section{The Crisis of the Estado de las Autonomías}

Over the past six years, the Catalan regional authorities have grown increasingly defiant of the Spanish Constitutional Order. The turn to populist tactics and a more contentious brand of politics, especially the deliberate transgression by the Catalan authorities of the rules of the representative-democratic game as enshrined in the Constitutional order, are simultaneously symptomatic and exacerbating cause of the broader crisis of confidence amongst Spaniards about the nature and quality of their representative-democratic institutions. 
In the process of secessionist mobilization, the nationalist movement has increasingly supplemented its traditional romantic repertoire with a materialist discourse of economic grievance, according to which the Spanish central government is guilty of "fiscally plundering," even "robbing," the region as a whole - a potent populist trope in the doubly propitious climate of extremely high unemployment combined with severe regressions in social rights (Gillespie and Gray 2015).

Many on the left in Spain and internationally look with considerable sympathy on the mobilization in favour of self-determination and/or independence for Catalonia. There are multiple reasons why this is so - some more legitimate than others. However, one thing that tends to unite these left-wing sympathizers is their reliance upon and perpetuation of mystified and sociologically naïve accounts of the "popular, grass roots" bases allegedly fuelling the recent cycle of nationalist mobilization (e.g. Guibernau 2014). Such accounts ignore the crucial role played by the regional mass media and the regional authorities in the mobilization process, as well as the organic links between the Catalan government and regional administrative apparatus with such "civil society" organizations as the ANC and Òmnium Cultural (Olmeda 2014). In turn, implicit in these mystified accounts of the recent wave of mobilization is a rather whitewashed or romanticized indifference to the class composition as well as the hegemonic class project advanced by the Catalan nationalist movement (Martinez and Barceló 2014).

The left-wing "fellow travellers" of the secessionist surge insist upon the potential for the wave of secessionist mobilization to break left, at least in Catalonia and maybe even in the rest of Spain. By delivering a powerful blow against the existing constitutional order and the existing state, so these intellectuals/activists argue, the Catalan nationalist 
movement - even unwittingly - promises to provide a golden opportunity for a definitive break with austerity, or more utopian yet, might even precipitate a revolutionary turn of events (Ali 2014; Delgado 2012).

Such arguments underestimate the level of working-class alienation, indifference, even occasional hostility, toward the so-called "procés" in Catalonia, not to mention in the rest of the country. Nevertheless, if in the process of mobilization, anti-austerity and even anti-capitalist fractions were to manage to gain the upper hand within the nationalist movement, then the legal break with the constitutional status quo could perhaps translate into a re-equilibration much more favourable to experimentation with left-wing alternatives to neoliberal austerity and even with direct-democratic models of governance in Catalonia.

The prospect cannot be entirely ruled out. After all, over the course of the ongoing crisis, the party system in Catalonia has undergone a transformation at least as serious as the one underway in Spain. Significant fragmentation as well as polarization can be clearly detected.

The credibility of the center-right Catalan nationalist party Convergència Democràtica, recently rebranded the Partido Demócrata Catalán, has been significantly damaged, especially in the aftermath of scandalous revelations in 2013 about the Andorran and Swiss bank accounts of Jordi Pujol. This, in combination with the application of painful cuts, not to mention unemployment rates nearly equal to those of the rest of Spain, put the Catalan government in a bind not altogether dissimilar to that of its adversaries in Madrid. Indeed, by June of 2013 , there were clear indications of a possible impending sorpasso within the secessionist camp - as support for CiU dipped down to under $20 \%$ in polls, while its governing partner, Esquerra Republicana surged ahead. 
Regional premier Artur Mas called for an early election, held on the $27^{\text {th }}$ of September of 2015, declared as a plebiscite on independence, with the promise of a unilateral declaration to that effect should the forces campaigning in favour of it obtain a victory at the polls. For the purpose of the plebiscite, Mas would commit to the formation of an unprecedented electoral coalition under the banner of Junts pel Sí ("Together for Yes") - a coalition that includes Mas's own Convergència Democràtica, along with its governing partner Esquerra Republicana, as well as activists from heavily-subsidised "civil society" groups such as the ANC and Òmnium Cultural. Mas even agreed to sacrifice his own protagonism in the process, running as the number four candidate on the list.

The plebiscitary election temporarily suspended the prospect of sorpasso within the Catalan nationalist camp, substituting it with a post-partisan fusion of sorts. The Junts pel Si platform managed to win just under $40 \%$ of the vote, in an election marked by polarization and a record-high turn-out of $77 \%$. However, this translated into 62 seats, nine less than the sum of CiU and ERC in 2012, and 10 less than their sum in 2010.

Meanwhile, an "anti-system," even avowedly anti-capitalist, left has surged within the nationalist movement - the Candidatura d'Unitat Popular, which received $8.2 \%$ of votes and 10 seats. Though far from representing a groundswell, these "anti-system" votes still proved enough to push secessionist forces over the threshold of a parliamentary (if not electoral) majority, rendering the CUP a "king-maker" of sorts.

The CUP does present a substantially different class project to the one still hegemonic within the Catalan nationalist movement, at least in principle. Indeed, its advocacy and - to some extent, its internal practice - of radical direct democracy, including its support for democratic control of the economy, combined with its open opposition to the Euro - makes its project in crucial respects a less contradictory, more coherent 
alternative to neoliberalism than the one incarnated in Podemos (Botran 2012; Palmer 2016). However, in terms of its class composition, it ultimately suffers from the same weakness as Podemos, though in a more extreme fashion: namely, its inability to connect with, much less to mobilize, the bulk of the fragmented, depoliticized, and apathetic urban working classes.

After an intense internal debate that included a most unlikely assembly-vote tie of 1515-1515, the party would decide to use its leverage to condition the composition of the new Catalan government, forcing Mas to step down, albeit to be replaced by a hand-picked and loyal successor, Carles Puigdemont.

In the wake of the plebiscitary election, the new majority in the Catalan Parliament would invoke its "democratic mandate" to pass a resolution in which it solemnly declared the beginning of a unilateral "process of democratic disconnection" with the Spanish state, announcing its intention to disobey any Spanish laws or rulings of the Constitutional Tribunal contradicting the will of the Catalan people as expressed in the Catalan Parliament. Thereby ratcheting up further the confrontation between the Catalan regional authorities and the Spanish constitutional order. At the beginning of December, Spain's high court would predictably declare the parliament's resolution null and void - the fourth such clear verdict against the open defiance of Catalan authorities in less than two years, warning that the regional authorities were "ignoring the constitutional limits of political action," and in failing to respect the rule of law were jeopardizing one of the fundamental "bases of social peace" (http://www.tribunalconstitucional.es/es/jurisprudencia/paginas/Sentencia.aspx?co $\underline{\mathrm{d}=21437)}$. 
The constitutional prescriptions for coping with such a crisis are in principle quite clear. Article II of the Spanish Constitution declares "the indivisible unity of the Spanish nation." Moreover, in Part VIII, dedicated to the Territorial Organization of the State, Section 155.1 states in no uncertain terms that "If a Self-governing Community does not fulfil the obligations imposed upon it by the Constitution or other laws, or acts in a way that is seriously prejudicial to the general interest of Spain, the Government, after having lodged a complaint with the President of the Self-governing Community and failed to receive satisfaction therefore, may, following approval granted by the overall majority of the Senate, take all measures necessary to compel the Community to meet said obligations, or to protect the above-mentioned general interest." By compel, the use of force is explicitly sanctioned. And Section 155.2 renders further explicit that "[w]ith a view to implementing the measures provided for in the foregoing paragraph, the Government may issue instructions to all the authorities of the Self-governing Communities."

But constitutional prescriptions do not always reflect the real dynamics working to constrict and constrain the horizons of the politically-possible. The Catalan nationalists' defection from constitutional loyalty has already significantly undermined, perhaps critically, the governability of the country from within the confines of that order. Though a demographic minority, their will may simply prove too powerful to ignore. This because the Catalan nationalists have long been hegemonic in the regional parliament and in the regional state apparatus more generally (Martinez 2002; Miley 2006).

Which means, at the end of the day, even if high-level functionaries were all sacked, the mid-level functionaries who would be called upon to implement any possible instructions from the central government following the nominal suspension of autonomy in accordance with Section 155 would themselves likely overwhelmingly pertain to Catalan 
nationalist ranks. The efficacy and effectiveness in implementing the will of the Spanish government under such circumstances can be expected to be quite low. The repeated defiance of the Catalan educational system, its refusal to implement recent High Court rulings mandating an increased presence of Castilian in the primary and secondary schools, is perhaps indicative in this regard (Garvía and Miley 2013). On the other hand, most functionaries likely lack sufficient conviction to risk losing their highly-coveted permanent jobs, it seems safe to assume that at least a minimum level of compliance can be expected. Here is the crucial test for the nationalist movement - will the functionaries of the Catalan regional government have the courage of their nationalist convictions to risk their jobs?

In principle, both the rule of law and the balance of coercive force remain on the side of the Spanish government in the on-going conflict with the Catalan authorities. However, in practice the Constitutional order requires the consent of the Catalan authorities, who have always sociologically been a crucial base of the stability of the constitutional order.

To invoke the terms of structural-functionalism, the balance of integrative forces holding the country together has certainly shifted over the past forty years of democratic rule in Spain. Economic integration into Europe has meant an end to any benefit of belonging to a protected Spanish market. At the same time, political integration into Europe, combined with military integration into NATO, has meant an end to the threat of military coup and authoritarian backlash. As a result, both carrots and sticks facilitating the cohesion of the country's quasi-federal system have over time been eroded. Meanwhile, the hegemony of the Catalan nationalist movement over the emergent regional state apparatus, the regional mass media, and especially the educational system, have changed 
the contours of dominant "social imaginaries," and therefore the balance of "reasonable" horizons of pragmatic compromise and consent, in a creeping, centrifugal direction.

The turbulence of the economic-cum-political crisis has provided the Catalan nationalist movement with an opportunity to channel a groundswell of discontent amongst threatened middle classes into the illusion of Catalan independence. There is by no means a clear majority, much less a supermajority, in Catalonia in favour of this illusion. But an overwhelming minority committed to this goal has managed, in the context of the crisis, to rapidly shift the terrain of the center ground, the terms of common sense, decisively in that direction in Catalonia. Witness the clear majority in the Catalan Parliament in favour of the so-called "right to decide" - the right to hold a referendum. Witness as well the clear majority in favour of something like the Basque fiscal deal as well, and for further Constitutional entrenchment of Catalan jurisdiction over language policy and education (though reliable surveys of the attitudes of the general public about such possible policies have been surprisingly sparse).

The Catalan nationalists' determination to forge ahead in their rebellion against the Constitutional order has already forced many issues nearly unthinkable just a few years ago, and certainly has the potential to create new facts on the ground. But so too have they provoked a backlash, a surge in support for measures of re-centralization in the rest of the country, not to mention a considerable amount of polarization in Catalan society itself.

The European context is also of course crucial. The European Community is, after all, nominally a community based upon the rule of law, and the Spanish authorities certainly have the rule of law on their side. Nevertheless, in the court of European and perhaps even world public opinion, the Spanish authorities remain suspect of authoritarian leanings, over forty years after Franco's death, and the Catalan nationalist cause symbolically associated 
still with the struggle against fascism in Spain, and therefore with democracy. Any compulsory suppression of the expressed will of the Catalan regional government is likely to be widely interpreted through such a lens. On the other hand, the consummation of a unilateral declaration of independence on the part of the Catalan authorities stands little chance of recognition by European authorities, and the possible majority in favour of independence quickly vanishes once the prospect of exclusion from Europe is entered into the equation.

Thus far, the Spanish authorities have refrained from invoking Section 155 of the Constitution. However, former premier Artur Mar, along with two other members of his government, are set to face trial, charged by the Spanish general attorney with "disobedience, perverting the course of justice, misuse of public funds, and abuse of power in relation to the unofficial referendum on Catalan independence" held in November 2014. (https://www.theguardian.com/world/2014/nov/21/catalan-president-face-severalcharges-after-unofficial-independence-referendum). A similar fate will likely meet current premier Carles Puigdemont, as well as current president of the Catalan Parliament, Carme Forcadell, come Fall, for deliberating disobeying the orders of Spain's High Court and forging ahead with the so-called "process of disconnection" (http://www.eldiario.es/catalunya/politica/Gobierno-TC-Forcadell-responsabledesobediencia 0 542445979.html).

In addition to such legal measures, other less legitimate tactics have been pursued as well, as the tape of Spain's Minister of the Interior, Jorge Fernández Díaz, encouraging the head of the Catalan Aunti-fraud Office to dig up information to discredit secessionist politicians - a tape which surfaced just five days before the second general election - has 
revealed (http://www.publico.es/politica/fernandez-diaz-conspiro-jefe-oficina.html). Such troubling indicators suggest that an end to the still-escalating confrontation between the Spanish and Catalan authorities is nowhere in sight.

There are nevertheless serious pressures by powerful actors both within Spain and in Europe for a compromise, even if it means a constitutional rupture - allowing for a referendum on the issue of independence, and perhaps the concession of a Basque-style fiscal deal as well. The support lent by five Convergència deputies for the composition of the Mesa del Congreso that had been pacted by the PP and Ciudadanos three weeks after the second election led some to speculate that both sides had reached a point where they might be willing to step back from the precipice of ever-further confrontation. But by the end of July, such speculation had ceased, after the Catalan Parliament passed another resolution reaffirming its commitment to the "process of disconnection." Evidently, the current balance of political forces both within Catalonia and across the country precludes such a de-escalation for now.

If the outcome of the crisis of the country's constitutional regime thus remains an open question, the regime of austerity would seem safely entrenched. The conflict between Spanish and Catalan authorities has yet to include any significant divergence in terms of the commitment to austerity expressed and pursued by public officials at both levels of government. A most telling episode in this regard would occur in the Spring of 2016. When Spain's budget minister Cristobal Montoro announced the country's deficit figures in late March, he explicitly blamed "overspending by regional governments," and singled out for particular admonishment the Catalan authorities, whom he jibed had "spent 2015 deciding whether or not to call elections" instead of focusing on the deficit 
(http://www.bloomberg.com/news/articles/2016-05-13/send-the-troika-back-to-spain-

catalan-finance-chief-says). The Catalan government replied, in the person of its Vice President, the head of Esquerra Republicana, Oriol Junqueras, by requesting European authorities to send another team of inspectors to Spain, and indeed suggesting "that European officials should intervene in the national budgeting process because the central government's decisions are 'arbitrary, inefficient and unjust' while ignoring EU guidance." In Junqueras' words: "We're delighted to collaborate with European institutions ... Better a mission in situ than a fine" (http://www.bloomberg.com/news/articles/2016-05-13/sendthe-troika-back-to-spain-catalan-finance-chief-says). A reply which certainly bodes ill for the plausibility of the illusion that the rise of Esquerra Republicana and the pending demise of Convergència might provide an opportunity for the region to break with austerity.

Even in the unlikely event that the channelling of citizen indignation in a decidedly nationalist direction were to lead to the emergence of a more than nominally left-wing nationalist power bloc dominant at the level of Catalan party politics, one openly committed to a break with austerity, the likelihood that such a power bloc could remain hegemonic if it were to openly embrace exit from the Eurozone is close to nil. In this respect, the lesson of the resounding electoral defeat suffered by the Left Platform in Greece, in its opposition to the pragmatic capitulation of Syriza before the demands of the Troika, should not be so swiftly swept under the rug by left-wing enthusiasts of the current secessionist surge. The vast majority of the Catalan public, even the vast majority of those who dream of "independence," remain committed to the European project, and even to the Eurozone. Which means that Catalan "independence," even if the process were to result in the ascent of nominally left-wing forces in Catalonia, is highly unlikely to entail an effective break with 
austerity. At least insofar as the Catalan public has a say in the terms of its "selfdetermination."

Of course, the scenario of forced exclusion from Europe could create political opportunities for the "independentist left" that would be highly unlikely to materialize through deliberate choice in the ballot box. But forced exclusion could only occur after international recognition of Catalan independence, to begin with - a scenario also highly unlikely to occur, unless the Spanish authorities were to commit the tremendous blunder of responding to a unilateral declaration of independence with aggressive executive decrees and excessive coercive force.

\section{Conclusion}

The economic-cum-political crisis has hit Spain like an earthquake, suddenly exposing underlying structural weaknesses of its constitutional edifice accumulated over the past decades. The explicit defection of the Catalan authorities from loyalty to that order renders the edifice susceptible to collapse.

Thomas Jefferson once complained that constitutions represent the tyranny of the dead over the living. For the constitutional order to survive, it must avoid appearing as such - not only among citizens in the country at large, but, perhaps especially, among a minority as powerful as the Catalan regional authorities. Especially in the European context, especially given the history of Spain, any resort to coercive force on the part of Spanish central authorities, even to uphold the Constitution, will be widely interpreted as authoritarian intransigence working to suppress the legitimate democratic aspirations of the Catalan people. 
This gap between legality and legitimacy could well determine the denouement of the current impasse, in favour of compromise, which means in practice further devolution, though not full-fledged sovereignty. Regardless of what the letter of the Constitution says. After all, the spirit of the 1978 Constitutional order is one of compromise amongst the de facto pillars of stability in Spanish society, including crucially the Catalan middle classes. On the other hand, the polarization associated with the mobilization in favour of secession has triggered a backlash as well, rendering the will to compromise more feeble on both sides of the nationalist divide.

In the meantime, the fact that the political agenda remains so firmly focused on the Catalan question has undoubtedly benefitted the Spanish right, granting it the opportunity to wrap itself proudly in the Spanish flag, to stand firmly as defender of the territorial integrity of the nation and of the constitutional order against the threat of the separatistas, to shift the focus of attention away from the subjects of corruption and austerity (ChaquésBonafont 2015: 109). Indeed, the confrontation with the Catalan authorities continues to serve as a most effective smokescreen, capable of channelling some citizens' indignation, while simultaneously dividing and conquering them, pitting middle-class and some workingclass segments against each other, imagined as "national" enemies, while reproducing and exacerbating the alienation of most working-class Spaniards from the terms and horizon of contestation in public debate, thereby fending off the fundamental threat of fissure of society throughout the country, and beyond, along class lines.

But the ratcheting up of the "territorial cleavage" vis-à-vis Catalonia has also contributed to the country's inability to form a government. As Bonnie Field has pointed out, "between 1982 and 2011 (before the party system changed), on average it took 37 days between elections and investiture." But now two elections and nearly nine months have 
come and gone, and still the formula for forging a majority sufficient for securing the investiture of a Prime Minister continues to elude the Spaniards.

After the general election of 1996, when the PP found itself in a similar situation, with a parliamentary plurality but short of an absolute majority, it could count on the support of the Catalan and Basque nationalists to secure a stable conservative governing majority, in exchange for concessions. But the repetition of such an alliance has by now become anathema on both sides of the territorial divide. Nor does the salience of the Catalan question only inhibit the formation of a right-leaning governing majority. To the contrary, the fundamental divergence in the approaches of Ciudadanos and Podemos to the "national" question, emblematically captured in the leadership of Podemos's insistence upon the Catalan demos's so-called "right to decide" its future status with the rest of the country via referendum, has heretofore rendered impossible any PSOE-CiudadanosPodemos alliance as well. Likewise, the Catalan nationalists' open defiance of the constitutional order, combined with their insistence on a unilateral referendum as a condition for any pact, have hindered the potential for any agreement with an alreadydivided PSOE, whose leadership justifiably fears that such a move could end up tearing the party apart.

While European authorities and the more conservative among Spaniards have grown increasingly nervous over this extended period of government-less governance, the sentiment of many on the left was captured well by Francisco Jurado, who in late August quipped on Twitter, "Better the institutional impasse we already know than a PP-C's government we have meet" (https://twitter.com/SuNotissima/status/769857718026903552). It remains to be seen how 
the current impasse will conclude, but whatever governing majority is ultimately formed, it is likely to be a very weak one, regardless of whether there are new elections. Meanwhile, the Catalan regional authorities increasingly defy the country's constitutional order. But despite all this uncertainty, austerity remains for now the only game in Spain.

\section{Bibliography}

Ackerman. 1993. We the People: Foundations. Cambridge, MA: Harvard University Press.

Aguilar and Oakley. 2002. Memory and Amnesia: The Role of the Spanish Civil War in the Transition to Democracy. Berghahn Books.

Ali. 2014. "Catalan Independence, Scotland, and the Middle East," Counterpunch. 22 Oct. http://www.counterpunch.org/2014/10/22/catalan-independence-scotland-and-themiddle-east/.

Anduiza, Bosch, Orriols, and Rico, eds. Elecciones generales 2011. Madrid: Centro de Investigaciones Sociológicas.

Ayala Cañon. 2014. Desigualdad y pobreza en España en el largo plazo. Madrid: Fundación FOESSA.

Ayala Cañon and Ruiz-Huerta, eds. 2015. Segundo Informe sobre la Desigualdad en España. Madrid: Fundación Alternativas.

Barreiro. 2013. "Blancanieves y el espejo mágico," Infolibre, 1st of June.

Bonime-Blanc. 1987. Spain's Transition to Democracy. New York: Westview Press.

Botran. 2012. Unitat Popular. La construcció de la CUP i l'independentisme d'esquerres. Lleida: Edicions El Jonc.

Busch, Hermann, Hinrichs, and Schulten. "Euro Crisis, Austerity Policy, and the European Social Model." http://library.fes.de/pdf-files/id/ipa/09656.pdf.

Calvo. 2013. "Fighting for a Voice: the Spanish 15-M/Indignados Movement in Spain" in Understanding European Movements: New Social Movements, Global Justice Struggles, AntiAusterity Protest. Laurence Cox and Cristina Flesher Fominaya, eds. London: Routledge, pp.236-253. 
Calvo and Alvarez 2015. "Limitaciones y exclusiones en la institucionalización de la indigación: del 15-M a Podemos," Revista Española de Sociología 24: 123-131.

Chaqués-Bonafont, Palau and Baumgartner. 2015. Agenda Dynamics in Spain. New York: Palgrave MacMillan.

Colomer. 2000. Strategic Transitions. Baltimore, MD: The Johns Hopkins University Press.

Cordero and Montero. 2015. "Against Bipartyism, Towards Dealignment? The 2014 European Election in Spain," Southern European Society and Politics, 20(3): 357-379.

Delclós. 2014. "Podemos: The Political Upstart Taking Spain by Force," Roar Magazine, 9 Dec. https://roarmag.org/essays/podemos-the-political-upstart-taking-spain-by-force/.

Delgado. 2012. "Tres razones para apoyar la independencia," 12 Sept. http://manueldelgadoruiz.blogspot.com/2012/09/tres-razones-para-apoyar-la.html.

Doménech. 2014. "Sueltos (I): Sobre la crisis de la Segunda Restauración borbónica y el llamado 'conflicto territorial." http://www.sinpermiso.info/textos/index.php?id=6757.

The Economist. 2013. "On Being Propped Up: The Spanish Economy," $25^{\text {th }}$ of May.

Flescher Fominaya. 2014. "'Spain is Different': Podemos and 15-M." http://blogs.Ise.ac.uk/eurocrisispress/2014/06/04/spain-is-different-podemos-and-15-m/

Garvía and Miley. 2013. “'Linguistic Immersion' and Political Conflict in Contemporary Catalonia," European Journal of Language Policy 5(1): 5-40.

Gili et. al. 2013. "The Mental Health Risks of Economic Crisis in Spain: Evidence from Primary Care Centers," The European Journal of Public Health 23(1): 103-108.

Gillespie and Gray, eds. 2015. Contesting Spain? The Dynamics of Nationalist Movements in Catalonia and the Basque Country. New York: Routledge.

Gramsci. 1971. Selections from the Prison Notebooks. New York: International Publishers.

Guibernau. 2014. "Prospects for an Independent Catalonia," International Journal of Politics, Culture and Society 27: 5-23.

Gunther, Montero and Botella. 2004. Democracy in Modern Spain. New Haven, CT: Yale University Press.

Heywood. 2007. "Corruption in Spain," PS, Issue 4 (October): 695-699.

Hirschman. 1991. The Rhetoric of Reaction. Cambridge, MA: Harvard University Press. Izquierdo. 2013. “iCosa más grande este Rajoy!”, El País, 29th of May. 
Jordana. 2014. "'Public Spending Cuts in Spain Have Been More Severe in Those Areas Under the Control of Regional Governments." http://blogs.Ise.ac.uk/europpblog/2014/02/06/public-spending-cuts-in-spain-have-beenmore-severe-in-those-areas-under-the-control-of-regional-governments/

Jiménez. 2004. "The Politics of Scandal in Spain," American Behavioral Scientist 47(8): 10991121.

Jiménez. 2009. "Building Boom and Political Corruption in Spain," Southern European Society and Politics 14(3): 255-272.

Legido-Quigley et al. 2013. "Erosion of Universal Health Coverage in Spain," The Lancet, Vol. 382, No. 9909: p.1977.

Linz. 1978. The Breakdown of Democratic Regimes. Crisis, Breakdown, and Reequilibration. Baltimore: The Johns Hopkins University Press.

Linz and Stepan. 1996. Problems of Democratic Transition and Consolidation. Baltimore, MD: The Johns Hopkins University Press.

López. 2014. “¿Por qué la corrupción se ha convertido en sistema,” El Público. Nov. 7, 2014. http://blogs.publico.es/contraparte/2014/11/07/por-que-la-corrupcion-se-ha-convertidoen-sistema/

Lustick. 1993. Unsettled States, Disputed Lands. Ithaca: Cornell University Press.

Machiavelli. 1950. The Prince and the Discourses. New York: Random House.

Maravall. 1982. The Transition to Democracy in Spain. London. Palgrave MacMillan.

Maravall. 1982. The Transition to Democracy in Spain. London. Palgrave MacMillan.

Maravall. 1993. "Politics and Policy: Economic Reforms in Southern Europe," in Bresser Pereira, Maravall, and Przeworski, eds., Economic Reforms in New Democracies: A SocialDemocratic Approach. Cambridge: Cambridge University Press, 77-131.

Maravall. 1999. "Accountability and Manipulation," in Przeworski, Stokes, and Manin, eds., Democracy, Accountability, and Representation. Cambridge: Cambridge University Press, 154-196.

Maravall. 2013. "En el túnel," El País, 14 May.

Martinez-Herrera. 2002. "From nation-building to building identification with political communities: Consequences of political decentralisation in Spain, the Basque Country, Catalonia and Galicia." EJPR 41(4): 421-453. 
Martinez-Herrera and Barceló. 2014. "Identidades y nacionalismos territoriales en las elecciones autonómicas de 2011-2012." Pp. 307-338 in Pallarés (ed.) Las elecciones autonómicas de 2009-2012. Madrid: Centro de Investigaciones Sociológicas.

Miley. 2006. Nacionalismo y política lingüística. El caso de Cataluña. Madrid: CEPC.

Montero. 1997. "El debate sobre el sistema electoral: rendimientos, criterios y propuestas de reforma," Revista de Estudios Políticos 95: 9-46.

Muñoz, Anduiza and Rico. 2014. "Empowering Cuts? Austerity Policies and Political Involvement in Spain," in How Welfare States Shape the Democratic Public: Policy Feedback, Participation, Voting, and Attitudes. (pp. 19-40). London: Edward Elgar Publishing Ltd.

Navarro. 2006. El subdesarrollo social de España. Causas y consecuencias. Barcelona: Editorial Anagrama.

Olmeda. 2014. "Mobilization from Above? The Dynamics of Catalan Nationalist Radicalization and Failed Federal Accomodation in Contemporary Spain, 1996-2014." Paper presented at Resurrections: The $21^{\text {st }}$ International Conference of Europeanists, Washington, D.C.

Oñate. 1998. Consenso e ideología en la transición política española. Madrid: Centro de Estudios Políticos y Constitucionales.

Palmer. 2016. From the margins to the forefront: Understanding the Candidatura d'Unitat Popular through a study of its evolution, ideological positions, and current situation. Bachelors of Arts Dissertation, University of Birmingham.

Ruiz-Huerta. Editor. 2013. Primer Informe sobre la Desigualdad en España. Madrid: Fundación Alternativas.

Przeworski. 1985. Capitalism and Social Democracy. Cambridge: Cambridge University Press. Przeworski. 1991. Democracy and the Market. Cambridge, MA: Cambridge University Press. Santamaría. 2012. “Signos de descomposición,” El Viejo Topo 294-295, Jul-Aug., 9-13.

Stobart. 2014. "Understanding Podemos." http://left-flank.org/author/lukestobart/

Streeck. 2011. "The Crises of Democratic Capitalism," in The New Left Review, no. 81, Sept.Oct., 5-29.

Uxó and Álvarez. 2016. "Is the End of Fiscal Austerity Feasible in Spain? An Alternative Plan to the Current Stability Programme (2015-2018)." DT 2016/2. 
http://www.uclm.es/dep/daef/DOCUMENTOS\%20DE\%20TRABAJO/DT-2016/2016-2\%20DTDAEF.pdf.

Uxó, Febrero and Bermejo. 2016. "Crisis, Unemployment, and Internal Devaluation in Spain," in Myant, Theodoropoulou, and Piasna, eds. Unemployment, Internal Devaluation, and Labour Market Regulation in Europe. ETUI, 127-167. http://www.etui.org/Publications2/Books/Unemployment-internal-devaluation-and-labourmarket-deregulation-in-Europe.

Villoria, Ryzin, and Lavena. 2013. "Social consequences of government corruption: A study of institutional disaffection in Spain," Public Administration Review 73(1): 85-94.

Wilson. 2012. "Multi-level party systems in Spain," Regional \& Federal Studies, 22(2): 123139. 